\title{
Religiosos em armas: o motim dos agostinhos da Congregação da Índia Oriental (Goa, 1638)
}

\author{
Margareth Almeida Gonçalves ${ }^{*}$ \\ ${ }^{1}$ Universidade Federal Rural do Rio de Janeiro, Seropédica/RJ - Brasil
}

\section{RESUMO}

Este artigo analisa o movimento de independência e autonomia dos religiosos da Congregação da Índia Oriental, na tentativa de ruptura com a casa mãe da Província de Portugal da Ordem dos Eremitas de Santo Agostinho, no ano de 1638. O uso de armas pelos religiosos sublinhou a violência da revolta. A década de 1630 correspondeu a anos de tensóes para os agostinhos do Oriente com ressonâncias nos centros de poderes régio e eclesiástico em Goa, Lisboa, Madri e Roma. Parte-se da leitura de códices, com vasta documentação gerada no âmbito da burocracia da Congregação de Propaganda Fide em Roma, acrescida de um conjunto de missivas entre o vice-reinado do Estado da Índia e o centro de Madri. A reflexão desdobra-se em três segmentos: a ação missionária agostiniana no Oriente; as conjunturas imperiais da década 1630 e as instituiçôes agostinianas em Goa; e o levantamento de junho de 1638.

Palavras-chave: Congregação da Índia Oriental; agostinianos; motim; Goa; Portugal; Propaganda Fide.

DOI: http://dx.doi.org/10.1590/2237-101X02104306.

Artigo recebido em $1^{\circ}$ de novembro de 2018 e aceito para publicação em 20 de março de 2019.

Este artigo integra pesquisa financiada pelo Edital Universal MCTI/CNPq 2016. A abordagem geral do texto foi apresentada pela primeira vez no Ciclo de Conferências "O Atlântico Ibero-Americano (sécs. XVI-XX). Perspectivas historiográficas recentes - 2017" no CHAM-Centro de Humanidades, Faculdade de Ciências Sociais e Humanas da Universidade Nova de Lisboa. Agradeço a Roberta Stumpf pelo convite e a Mar Garcia Arena, Miguel Dantas da Cruz, Mafalda Soares da Cunha e Graça Almeida Borges pelos comentários. Na pesquisa contei com o generoso apoio de Ângela Barreto Xavier, que forneceu a referência sobre uma extensa documentação do levantamento objeto deste artigo pertencente à Biblioteca Nacional de Portugal.

* Professora da Universidade Federal Rural do Rio de Janeiro / Departamento de História, Seropédica/RJ Brasil. E-mail: mdagoncalves@gmail.com. ORCID: https://orcid.org/0000-0002-8873-6519. 


\section{Religious men in arms: the riot of the Augustinians of the East India Congregation (Goa, 1638)}

\section{ABSTRACT}

This paper analyzes the movement of independence and autonomy of the East India Congregation and the attempt of rupture with the Mother House of the Portuguese Augustinian Province in the year 1638. The use of weapons by religious men highlighted the violence of the upheaval. The decade of 1630 corresponded to years of tensions for the Augustinians of the East, with repercussions in the centers of royal and ecclesiastical powers in Goa, Lisbon, Madrid and Rome. The reading of a codex with extensive documentation, generated within the bureaucracy of the Congregation of Propaganda Fide in Rome is the starting point, in addition to a set of missives between the viceroyalty of the Estado da India and Madrid. The approach unfolds in three segments: the Augustinian missionary activity in the East, the imperial conjunctures of the 1630s and the Augustinian institutions in Goa, and the June 1638 uprising.

Keywords: East India Congregation; augustinians; religious riot; Goa; Portugal; Propaganda Fide.

\section{Religiosos en armas: el motín de los agustinos de la Congregación de las Indias Orientales (Goa, 1638)}

\section{RESUMEN}

Este artículo analiza el movimiento de independencia y autonomía de los religiosos de la Congregación de las Indias Orientales, en la tentativa de ruptura como la casa madre de la Provincia de Portugal de la Orden de los Eremitas de Santo Agostino, en el año 1638. El uso de armas por los religiosos destacó la violencia de la revuelta. La década de 1638 correspondió a los años de tensiones para los agustinos de Oriente con resonancias en los centros de poder reales y eclesiástico en Goa, Lisboa, Madrid y Roma. Se parte de la lectura de códices, con vasta documentación generada en el ámbito de la burocracia de la Congregación de Propaganda Fide en Roma, aumentadas de un conjunto de misivas entre el vice reinado del Estado de las Indias y el centro de Madrid. La reflexión se despliega en tres segmentos: la acción misionaria agustina en Oriente; las coyunturas imperiales de la década de 1630 y las instituciones agustinas en Goa; el levantamiento de junio de 1638.

Palabras clave: Congregación de las Indias Orientales; Agustinos; motín; Goa; Portugal; Propaganda Fide. 
Em 2 de agosto de 1638, o vice-rei do Estado da Índia Pero da Silva (1635-1639) anuncia de Goa a Filipe III de Portugal a "conspiração e motim" dos agostinhos da Congregação da Índia Oriental, o "maior escândalo" ocorrido naquela República. Informa acerca da destituição do "honrado" provincial, frei João de Mesquita, seguida da nomeação em capítulo, no convento de Nossa Senhora da Graça, do novo eleito, frei Antão de Jesus, o ancião dos frades nascidos na Índia (ANTT-DRI, livro 43, fls 97-98v). O vice-rei atenta ao seu empenho em manter a concórdia e a união, pela garantia do princípio de harmonia social. Recorre ao vocabulário propagado pelo paradigma aristotélico-tomista, pilar da funcionalidade do pensamento político-teológico-jurídico da segunda escolástica, garantidor da preservaçáo da unidade dos súditos no "corpo místico" de uma monarquia de caráter providencial. ${ }^{1} \mathrm{Na}$ percepção do vice-rei, o vocábulo "motim" explicita a torpeza do movimento, próximo às arruaças de gente vil. Afinal, o termo vinculava-se a tumultos não de todo desprovidos de violência. ${ }^{2}$ No levante dos agostinhos reconhece-se a linguagem do aparato ritualístico desse tipo de manifestação: a convocação dos religiosos no convento pelo toque dos sinos, a animação noturna, a murmuração em conluios, panfletos e armas. Na mesma extensão de movimentos conflituosos endêmicos das sociedades da época moderna e igualmente no Império Habsburgo, a conspiraçáo denunciou, por um mau governo, a Província de Portugal da Ordem dos Eremitas de Santo Agostinho no reino. Clamou por independência, na afirmação do ius commune da tradição ibérica que, segundo os levantados, asseverava a autonomia de governo dos agostinhos da Índia. O movimento reivindicava a criação de uma província agostiniana no Oriente. ${ }^{3}$

Dois meses antes da data da advertência do vice-rei, em 2 de junho, os independentistas assinaram um termo de juramento de rompimento com a Província de Portugal, sob a acusação de governo intruso - "sem respeito e disposição das nossas leis e sagradas constituiçóes". Alegavam ter se esgotado o prazo do tempo de governo da Província de Portugal e citam o breve do Papa Clemente VIII de 31 de janeiro de 1596, que erigiu a Congregaçáo da Índia

\footnotetext{
${ }^{1}$ Cabe relevar o predomínio no pensamento político em Portugal das acepçóes de direito natural investidos por Deus aos sujeitos em comunidade; "poder de sujeição" segundo a teoria de justificação em que o fim da respublica é o "bem comum", que fixa os limites do mando (TORGAL, 1982, p. 6-9; 13).

${ }^{2}$ Segundo Hespanha, "eram movimentos sem forma nem cabeça, tumultuários, embora de violência extrema” (2012, p. 45).

${ }^{3}$ Observe-se que a Ordem dos Eremitas de Santo Agostinho apresenta um modelo de administração centralizado, semelhante às demais ordens mendicantes. Formada por conventos dirigidos por um prior, a ordem integrava províncias regidas por um Prior Geral, sujeitas diretamente à Sé Apostólica em Roma. A fundação da ordem recua ao medievo. O papa Alexandre IV, através da bula Licet Ecclesiae Catholicae, em 9 de abril de 1256, confirmou a unificaçáo de cinco congregaçôes de eremitas ("Grande União"). As primeiras constituiçôes foram elaboradas na cidade de Ratisbonne no ano de 1290. Segundo a documentação existente, a presença dos agostinhos no território de Portugal remonta ao século XIII, subordinados à Província de Castela. A partir de 1387, as casas de Portugal foram organizadas na forma de um vicariato provincial, que respondia diretamente ao Prior Geral em Roma. A data de criação da Província de Portugal ocorreu entre 1476 e 1478. Veja-se SOUSA, 2005, p. 419-421.
} 
Oriental e empenhou um compromisso de autogoverno aos agostinhos da Índia. Denunciam a intimação dos confrades do Reino e a situação a que estavam reduzidos, privados "das honras da religiáo a muitos serviços e merecimentos bem devidos" (ANTT-DRI, livro 43, fl. 302). ${ }^{4}$ Elencam argumentos derivados das tópicas do direito natural ("como último remédio") e da liberdade ("conseguir nosso direito e devida liberdade"), forjadas no entendimento da concepção estamental do corpo social em chave retórica da teologia política escolástica. Explicam que a separaçâo não era uma "maliciosa coligação", ou "conspiração", infração proibida no capítulo segundo das constituiçôes da ordem, e defendem o fim justo e bom da açáo na recuperação do direito usurpado alia via feri potest (ANTT-DRI, livro 43, fl. 304v). O Termo de Juramento foi confirmado e assinado por frei Antão de Jesus, o provincial eleito pelos agostinhos levantados da Índia, e reteve os nomes de 76 religiosos apoiadores do movimento, todos com profissão no convento de Nossa Senhora da Graça em Goa. A conspiração expôs a configuração de dois grupos de religiosos na Congregação da Índia Oriental: os de profissão no Reino (em geral no convento de Nossa Senhora da Graça de Lisboa) e em Goa.

Sáo os desdobramentos em torno do motim dos agostinhos de 1638 na cidade indiana, capital do império português, que constituem o objeto de interesse deste artigo. Os primeiros religiosos da Província de Portugal da Ordem dos Eremitas de Santo Agostinho chegaram ao Índico seis décadas antes do ato de rebeliáo, no reinado de D. Sebastião I, em 1572. ${ }^{5}$ Ao final do quinhentos, o braço oriental dos eremitas agostinhos já se amoldava no formato de uma congregação sujeita à província no reino.

Nas primeiras décadas do século XVII, as tensôes entre o Padroado Régio português e Roma prosperaram na fundação da Congregação de Propaganda Fide, em 1622. Do mesmo modo, desde o quinhentos, as demandas das instituiçôes de clérigos regulares da Índia por autonomia tenderam a acentuar o conflito com as casas mães da metrópole. É relevante atentar aos processos de disputas dos braços franciscanos da Índia, observância e capucho, por independência frente às congêneres do reino (XAVIER, 2006, p. 87-116; XAVIER, 2014, p. 87-110; FARIA, 2013, p. 121-161). As conjunturas das variadas escalas dos conflitos dos franciscanos demonstram os componentes tensionais das instituiçóes religiosas na pretérita Roma do Oriente. O motim agostiniano de 1638 acrescenta elementos ao cenário de disputas políticas das ordens regulares em movimentos sucessivos que elegeram retóricas e estratégias institucionais na manipulação do jogo de interesses entre Goa, Lisboa e Roma.

Após franciscanos e dominicanos, terceira ordem mendicante a chegar ao Índico, em 1572, os Eremitas de Santo Agostinho mantiveram papel secundário nos processos de evangelização vinculados ao Padroado Régio de Portugal. A historiografia sobre os agostinhos no Oriente

\footnotetext{
${ }^{4} \mathrm{Na}$ sequência do artigo é referido por Termo de Juramento.

${ }^{5}$ Sobre questôes em torno da ordem dos eremitas de Santo Agostinho no reinado de D. João III e o envio das primeiras missōes agostinianas ao Índico, veja-se GONÇALVES, 2014, p. 107-141.
} 
sobreleva as contribuiçôes da fase do arcebispado do eremita de Santo Agostinho D. Frei Aleixo de Meneses (1595-1610-12), período que correspondeu à expansão da malha conventual agostiniana no Oriente, dobrando o número de sete para 15 conventos (ALONSO, 1992; FLANNERY, 2013; PINTO, 2006; PINTO, 2011, p. 153-180; GONÇALVES, 2014).

O motim dos agostinhos da Índia de 1638 não recebeu uma reflexão no âmbito da historiografia de história das missōes no Leste. Alusōes ao conflito estão dispersas em partes variadas da obra de Carlos Alonso, que, de forma específica, menciona os episódios do levantamento no estudo sobre as missóes agostinianas em Baçorá, no Golfo Pérsico. Nessa obra, Alonso faz alusão à negociação dos procuradores da Congregação da Índia Oriental na cúria romana, no bojo das disputas entre agostinianos e carmelitas na regiáo quanto à prioridade religiosa na jurisdição paroquial junto às comunidades designadas nas fontes portuguesas por "cristãos de São João" (ALONSO, 1967, p. 177-187).

Este artigo parte de algumas perguntas de cunho sociológico acerca da Congregação da Índia Oriental através do movimento de junho de 1638 . O que a rebelião permite esclarecer do desenho institucional e estratificação social da Congregação da Índia Oriental da ordem dos eremitas de Santo Agostinho de Portugal? Pode-se indicar um perfil social comum aos amotinados? Busca-se atentar ao delineamento dos grupos de professos agostinianos, o que inclui interligar as experiências balizadas pelo compartilhamento da mesma contemporaneidade, formação comum, cosmologia, comportamentos e sentimentos de pertencimento a determinada coletividade. $^{6}$

\section{Tensões agostinianas no "Monte Santo"}

1630, a "década desastrosa" no Estado da Índia, segundo a expressão de Sanjay Sumbramanyam, para as ordens religiosas foram anos de sucessivos embates com a instância vice-reinal. O quadro de tensôes intensificou-se durante o governo de D. Miguel de Noronha, alter ego do valido de Filipe IV de Espanha (Gaspar de Guzmán y Pimentel, conde-duque de Olivares) no processo de centralização da autoridade e de condução de uma política fiscal e do controle de bens patrimoniais das ordens regulares. D. Miguel de Noronha, conde de Linhares, partiu de Goa ao final do ano de 1635. Pero da Silva, o vice-rei velho ("vecchio"), conforme a designação reiterada ao longo de Relatione del caso successo sobre o movimento de junho de $1638^{7}$, foi o sucessor no governo (1635-1639), conduzindo uma política, em termos

\footnotetext{
${ }^{6}$ A base de dados dos religiosos agostinianos de atuação no Estado da Índia foi organizada a partir de informaçóes de uma extensa crônica de frei Manoel da Ave Maria (Manual Eremitico da Congregação da Índia Oriental dos eremitas de N.P.S. Agostinhos, 1817), além de fontes variadas e dispersas do século XVII. A transcrição da crônica de frei Manoel da Ave Maria foi publicada em REGO, 1955, p. 95-1008.

${ }^{7}$ Relatione del caso successo alli Religiosi di S. Agostino dell'India Orientale alli 17 di Giugno 1639 (A partir de agora entenda-se a referência ao longo do artigo por Relatione del caso successo) apresenta a incorreção do ano,
} 
externos mais passiva, e de relativo êxito na parte fiscal em comparação com o período do conde de Linhares (SUBRAHMANYAM, 1993, p. 233).

Conforme a historiografia assinala, o excessivo número de religiosos alinhou uma das denúncias de D. Miguel de Noronha às ordens religiosas (SUBRAHMANYAM, 1993, p. 233). ${ }^{8}$ Frei Gaspar de Amorim, o provincial dos agostinhos em Goa (1632-1636), afirma, em uma Resposta às acusações do vice-rei, com data de 8 de janeiro de 1636, ora encaminhada a Pero da Silva, que a Congregação da Índia Oriental nunca chegara a ultrapassar o contingente de 220 religiosos. Nessa mesma carta, o provincial realça que o Convento de Nossa Senhora da Graça em Goa abriga somente noviciado, formando religiosos para servirem nas missôes: "para as quais vaô depois de bem instruídos em virtude e letras" (ANTT-DRI, livro 35, fls. 177-180v, fl. 177). Os religiosos mais velhos, já não aptos ao trabalho missionário, permanecem do mesmo modo na casa de Goa, além daqueles "necessários para outros ministérios". Cita 11 conventos em cidades no Estado da Índia e cinco em "terras de mouros", a maioria de pequeno número de religiosos, salvo a casa mãe de Goa.

No que diz respeito ao cálculo de conventos e religiosos agostinianos no ano de 1635, indicado por António Bocarro, surge um contingente relativamente superior aos números de Gaspar de Amorim. Aos 16 conventos do provincial, o cronista e guarda-mor da Torre do Tombo de Goa acrescenta dois, entre os quais contabiliza Sinde, fundado em 1624 nas terras do "Gran Mogor", no entorno do Golfo de Cambaia. Nas crônicas agostinianas, a referência ao Sinde inclui a acepção "hospício" e não convento, em virtude da dimensão pequena e de poucos religiosos. Distribuídos pelos 18 conventos, Bocarro registra um total entre 292 e 302 religiosos, com significativa concentração nas casas de Goa: convento de Nossa Senhora da Graça (80 a 90 religiosos) e o colégio de Nossa Senhora do Pópulo (35 noviços) (BOCARRO, 1600-1699, p. 59-60).

O número em torno de 300 agostinianos atuantes na Ásia, conforme assinalado por Bocarro, indica um cômputo visivelmente superior às duas centenas da Resposta de Gaspar de Amorim. A despeito de eventuais inexatidôes nos registros, a desfasagem pode sugerir uma tendência do provincial agostiniano à redução do contingente de religiosos da Congregação da Índia Oriental, dirimindo, assim, o peso das acusações procedentes do vice-rei.

O prelado agostiniano acrescenta à réplica a resposta a um segundo ponto polêmico da denúncia de D. Miguel de Noronha. Nega que a congregação abrigasse um número excessivo de soldados, embora fosse obrigado a reconhecer a entrada de oito nos últimos dois anos,

que é 1638 e não 1639, integra um extenso códice da Biblioteca Nacional de Portugal (BNP) que reúne uma documentação variada da Congregação de Propaganda Fide sob o título de "Documentos religiosos relacionados com a Ordem de Santo Agostinho”. Manuscrito, Códice 1498 (a partir daqui é indicado pelas iniciais DRSA). Relatione del caso successo estende-se da fl. 5 a 30.

${ }^{8} \mathrm{E}$, para uma análise acerca das pressóes do vice-rei sobre as ordens religiosas tanto em relação aos bens de raiz como à entrada de significativo número de soldados nos conventos de Goa, é relevante o estudo de FARIA, 2012, p. 357-368, p. 364. 
entre 1634 e 1635. Não deixa de destacar a licença do vice-rei na admissão dos novos soldados no convento. No segundo ano (1635) registra a admissão de soldados meninos ("este anno tres escolhendo alguns mininos q ou saibão latim ou estejaô em idade $\mathrm{p}^{\mathrm{a}} \mathrm{o}$ aprender"), revelando um dos traços do recrutamento militar de moços a partir de 14 anos, também a idade mínima permitida de entrada em conventos. ${ }^{9}$

$\mathrm{Na}$ peroração à Resposta, o provincial acrescenta o drama dos soldados que vagueavam esfomeados pelas ruas de Goa, em que muitos morriam, alguns procuravam as portarias de conventos e outros buscavam servir a reis "gentios e mouros". E, de fato, avolumam-se os relatos sobre as condiçôes de pobreza da soldadesca, que fora do campo de batalha ou sem vínculos com as fortalezas e armadas do Estado da Índia, não recebia soldo ou mantimento — os atrasos em pagamentos por parte da Coroa foram contínuos. ${ }^{10}$ A migraçáo de soldados portugueses para ordens religiosas foi persistente desde o século da fixação dos portugueses no Oriente (MENDONÇA, 2002, p. 17-19). Virtude cristã e ação militar combinaram-se no modelo de soldado agente dos processos de conversão das populaçôes asiáticas ao cristianismo.

Atente-se ainda à localização das instituições agostinianas na colina de Nossa Senhora do Rosário - uma das antigas paróquias de Goa, criada em 1543 -, também denominada nas fontes de Monte Santo, em forte alusão ao simbolismo dos montes e montanhas na tradição do Antigo Testamento, como o Monte Sião em Jerusalém. No entorno de Nossa Senhora do Rosário, o convento de Nossa Senhora da Graça, o Colégio de Nossa Senhora do Pópulo, o Mosteiro de Santa Mônica, e, a partir de cerca de 1632, o Seminário de São Guilherme, compunham o complexo agostiniano. O antigo Seminário de São João Evangelista, fundado em 1622, transmudado em São Guilherme, celebrou-se pelo talento musical de seus pupilos. Voltado prioritariamente aos segmentos brâmanes da aldeia original do seminário em Neurá, recebeu também filhos de portugueses. Do estabelecimento de formação cristã saíram religiosos, clérigos e párocos, direcionados ao clero secular. Sublinhe-se o alinhamento institucional agostiniano em uma mesma área com a potência de conexôes e trocas de populaçôes de variadas procedências étnicas e religiosas através das suas edificaçôes.

Anni horribiles para os agostinhos: acresciam-se as dificuldades decorrentes dos conflitos persistentes entre o Mosteiro de Santa Mônica, de freiras agostinianas, e o Senado da Câmara de Goa, que perseverava na acusação de concentração de riqueza e sequestro de viúvas ricas. Em épocas de carestia e pobreza no Estado da Índia acusam os frades de retirarem do mercado matrimonial mulheres dos segmentos superiores católicos.

Cabe, entretanto, considerar um fato não apenas interessante, mas de maior significância para o entendimento dos movimentos de circulação entre as instituiçóes agostinianas de

\footnotetext{
${ }^{9}$ A prática do recrutamento de soldados incluiu provavelmente garotos na idade em volta de 14 anos. As Ordenaçóes Filipinas, livro 4, capítulo 83 (Dos testamentos dos soldados e pessoas que morrem na guerra), estabelecem em 14 anos a idade legítima dos soldados para a capacidade de fazerem testamento (ALMEIDA, 1870, p. 915-916).

${ }^{10}$ Vejam-se BOXER, 1981, p. 283-291 e RODRIGUES, 2004, p. 198-223, p. 214-222.
} 
Goa. Observe-se que, no bojo da crise das Mônicas com os poderes camarários, 1636 foi um ano que se iniciou com a sacralização do espaço do mosteiro através dos episódios associados ao "milagre" do crucifixo na Igreja - em alusão ao fenômeno do Cristo que da cruz se movimentara e abrira os olhos sucessivamente em direção às freiras localizadas no Coro (SANTA ANNA, 1640) - e a recepção da notícia da concessão de proteção real ao mosteiro (SILVA, 1855, p. 6). O ano finaliza, entretanto, de forma catastrófica com um incêndio de grandes proporçôes na véspera do Natal. Durante a fase de reconstrução do edifício, as Mônicas estiveram alojadas no Colégio do Pópulo. Instituiçôes irmãs, o Colégio do Pópulo, fundado em 1602, e o Mosteiro de Santa Mônica, quatro anos à frente, complementam a ocupaçáo física de terrenos contínuos ao Convento de Nossa Senhora da Graça. As novas edificaçóes, acrescidas da reforma do convento de Nossa Senhora da Graça, formaram o complexo arquitetônico, cujas obras foram iniciadas no período do arcebispado de D. Frei Aleixo de Meneses. Em 1637, ano anterior ao motim dos agostinhos, as religiosas retornaram ao mosteiro, reconstruído após as obras de recuperação.

E, de fato, ao término da década de 1630 as instituiçóes agostinianas do Monte Santo ardiam em movimentaçóes intestinas e pari passu no enfrentamento e contestação dos poderes civis do Império: autoridades camarária, vice-reinal e régia.

\section{"A cidade a ferro e fogo": o grupo dos levantados e as lideranças do movimento}

Em 1638, quais ligaçôes se podem estabelecer entre o encerramento da barra de Goa pela armada holandesa e a permanência de um número significativo de religiosos agostinianos na cidade? ${ }^{11}$ Os religiosos em trânsito no convento cimeiro da Congregação da Índia Oriental adiaram o retorno às respectivas missóes e conventos de origem por causa do urdimento do motim? O grupo de amotinados incluiu religiosos moços do Colégio do Pópulo? O Termo de Juramento dos agostinhos, com data de 2 de junho de 1638, acima citado, contém 77 nomes de apoiadores à criação de uma província autônoma e independente dos confrades do reino. Mas, como era formada a base religiosa e social da Congregação da Índia Oriental à época do levantamento? Qual foi a composição dos conventos nas missões agostinianas na Ásia? Perguntas que servem neste artigo como guia à reflexão, mas não de todo contempladas com respostas, perante o limite da documentação disponível até o presente.

Com efeito, à exceção da casa mãe de Goa, os demais conventos, de Mombaça a Malaca e Macau, reuniam um contingente entre três e 20 religiosos. A malha agostiniana agrupava 17 conventos em 1638 (Figura 1), o que permitiu, naquele momento, aos sublevados se vangloriarem de um número superior ao do conjunto de conventos no reino. Os números

\footnotetext{
${ }^{11}$ A atentar as reunióes do capítulo da congregação em Goa que ocorriam após o encerramento do período de bloqueio das barras de Goa (durante os anos de 1637 a 1644) no mês de maio.
} 
de agostinhos por regiáo no Oriente da listagem de António Bocarro confirmam a concentração de religiosos em Goa (Convento de Nossa Senhora da Graça e Colégio do Pópulo). Por sua vez, os números apontam como conventos de maior número de religiosos e, decerto, de relevância missionária, os localizados em Mascate (herança da posição de Ormuz na estrada do Golfo Pérsico), na praça mercantil de Cochim, em Baçaim pujante cidade na Província do Norte, em Colombo, no Ceilăo, e Ugulim, no golfo de Bengala.

Figura 1: Mapa dos conventos da Congregação da Índia Oriental, 1638

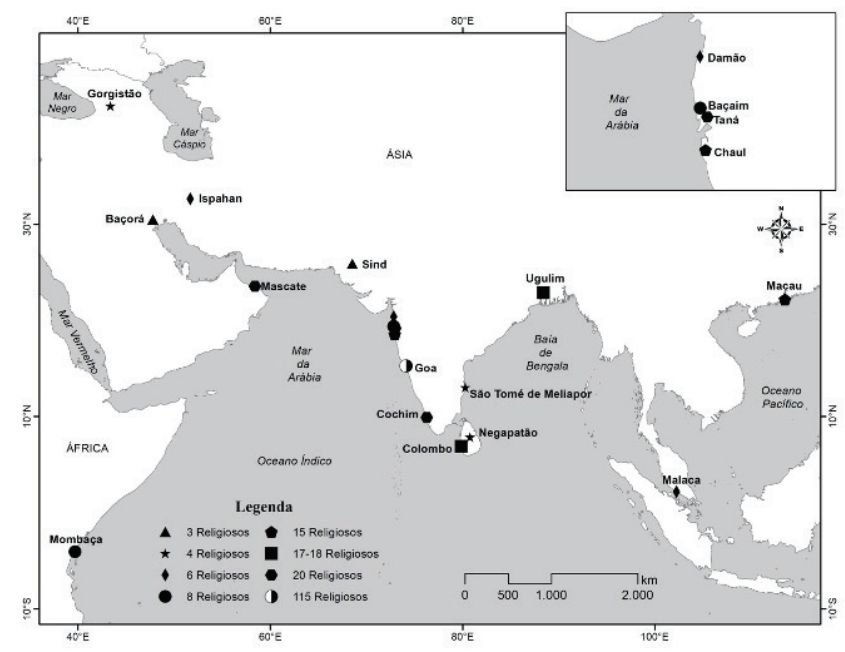

Fonte: REGO, 1955, p. 95-1008.

O topo da estrutura de governo da Congregação da Índia Oriental corresponde ao posto de vigário provincial, eleito pela Província de Portugal em capítulo reunido no convento de Nossa Senhora da Graça de Lisboa. Escolhidos pelo definitório de Lisboa, acresciam-se cargos superiores dos agostinhos no Oriente: o de prior do Convento de Nossa Senhora da Graça de Goa e reitor do Colégio de Nossa Senhora do Pópulo ${ }^{12}$, além dos quatro definidores ${ }^{13}$ e dois visitadores. A mediação com um ministro geral do centro romano da Ordem dos Eremitas de Santo Agostinho era efetivada pela Província de Portugal.

De acordo com os Estatutos da Congregação da Índia Oriental de 1632, fora orientação precípua do braço agostinho oriental a "conservação e o aumento da vinha do Senhor" através da "conversão dos idólatras e a redução dos cismáticos à Santa Igreja Católica" (APL, Mss 336, fls 8-14v.). A tradução das alteridades no Oriente operou-se através das rupturas produzidas pelas posiçóes do idólatra (o outro náo cristáo) e do cismático (o cristáo das mar-

\footnotetext{
${ }^{12}$ As três funçôes cimeiras da Congregação da Índia Oriental (vigário, prior e reitor) eram acompanhadas de três vias de sucessão, segundo os estatutos de 1632 por religiosos "q tenhaó as mesmas partes e sufficiencias" (APL, Mss 336, fl. 15v.).

${ }^{13}$ Os definidores deveriam ter a idade mínima de 30 anos e eram eleitos por um biênio (APL, Mss 336, fl. 13v.).
} 
gens). Tratava-se de reformar os excessos (costumes, falsas crenças) e os erros (teológicos), de povos islâmicos e das antigas cristandades ("cristáos de Sáo Tomé", armênios, georgianos e “cristãos de São João"), nas partes da costa africana ao Pacífico.

Alguns dados quantitativos da Congregação da Índia Oriental, desde a chegada dos primeiros 12 religiosos ao Índico, oferecem um perfil social singular e complexo da composição dos religiosos professos. ${ }^{14}$ Os registros de matrículas, no período entre 1572 e 1638, embora computados em bases imprecisas, segundo os parâmetros estatísticos atuais, indicam um universo em torno de 712 nomes. Desse contingente, 82\% dos religiosos (583) vestiram o hábito no convento de Nossa Senhora de Goa e 18\% em Portugal (Gráfico 1). Assinale-se um aumento acentuado do grupo de religiosos registrados no convento de Goa nas primeiras décadas do século XVII, que corresponde à expansão das missóes agostinianas após 1595, no arcebispado de D. Frei Aleixo de Meneses, e um novo movimento de crescimento a partir de 1620 (Gráfico 2).

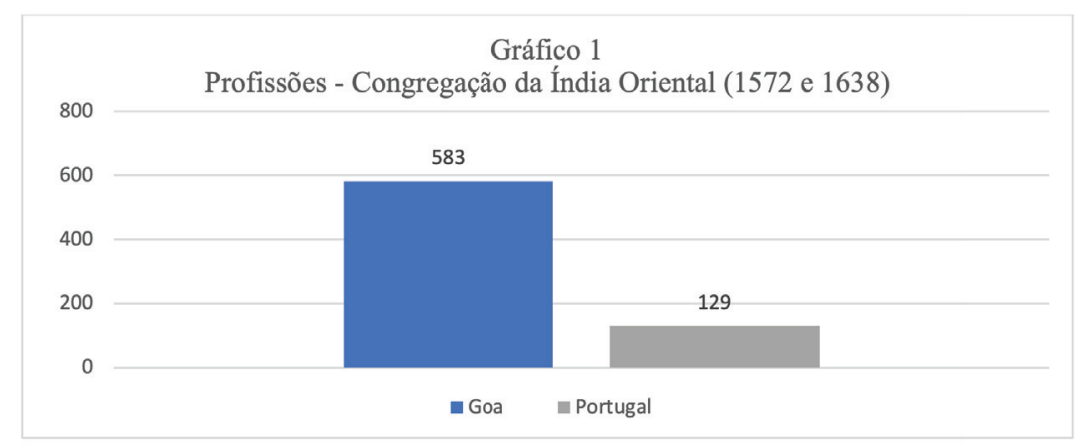

Fonte: REGO, 1955, p. 95-1008.

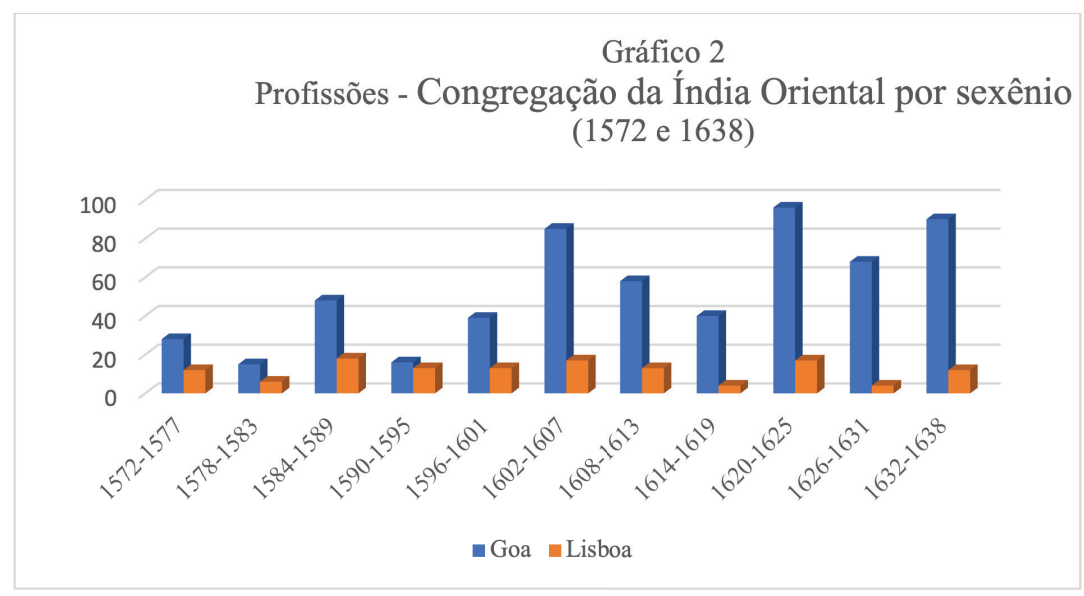

Fonte: REGO, 1955, p. 95-1008.

\footnotetext{
${ }^{14}$ Foi utilizada a base de dados citada na nota 7.
} 
Os gráficos projetam um recorte que conforma o grupo de profissão em Goa e de profissão em Portugal. O número inferior de reinóis sugere indícios da baixa atração das missóes do Oriente entre os agostinhos da metrópole, sinalizando a dependência na Congregaçáo da Índia Oriental, dos grupos “indianizados”, de profissão no Convento de Nossa Senhora da Graça de Goa. ${ }^{15}$ Registre-se, no Gráfico 3, a proporção majoritária entre os que vestiram o hábito na Índia (“indianizados") dos religiosos naturais do reino, 72\%, (417) e um segmento menor de 20\% (118) sobre os nascidos no Estado da Índia, predominantemente em Goa, e com índices inferiores, nas cidades de Cochim, Macau, Baçaim. Cabe ainda assinalar as hierarquias sociais que amoldaram as disputas e os conflitos na Congregação da Índia Oriental entre os portugueses reinóis e os "filhos" da congregação da Índia.

\section{Gráfico 3 \\ Procedência dos Agostinhos de profissão em Goa \\ (1572-1638)}

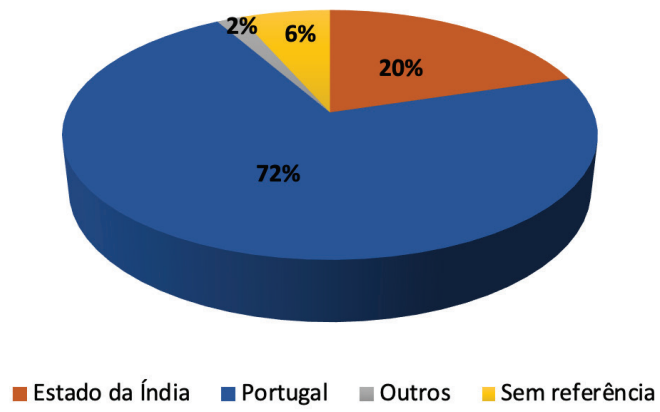

Fonte: REGO, 1955, p. 95-1008.

Todos os nomes dos independentistas no Termo de Juramento correspondem a religiosos com profissão no convento de Goa, embora a maioria dos 77 signatários fosse procedente de Portugal (Gráfico 3). Entre os líderes, dois portugueses, que vestiram o hábito com idade inferior a 20 anos: frei Manoel da Purificação e frei Simão da Graça.

Frei Manoel da Purificação, no século Manoel da Costa Pacheco, respondia ainda por "Caparica", na referência ao local de origem em Portugal. Vestiu o hábito aos 16 anos, em 11 de fevereiro de 1622, e professou um ano depois. Leu, ainda como irmão, o curso de Teologia em 1628. Foi sacerdote, pregador, confessor, mestre. Manoel da Purificação foi um dos procuradores in solidum da Congregaçáo da Índia Oriental, enviado a Roma na representação dos emancipadores, juntamente ao confrade frei Simão da Graça.

\footnotetext{
${ }^{15}$ A categoria “indianizado(s)" refere-se a religiosos com formação em Goa porém não necessariamente nascidos na terra, atenta aos segmentos de portugueses e também de naturais imbricados aos interesses locais de missão e poder. O recurso à categoria de “indianizado", em distinção à de reinóis, busca ampliar perspectivas de abordagem das hierarquias de subalternização e inferioridade do clero regular em Goa, incluindo os de naturalidade em Portugal com profissão e estudos em Goa, através do estudo de caso dos agostinhos.
} 


\section{Gráfico 4 \\ Procedência dos levantados(1638)}

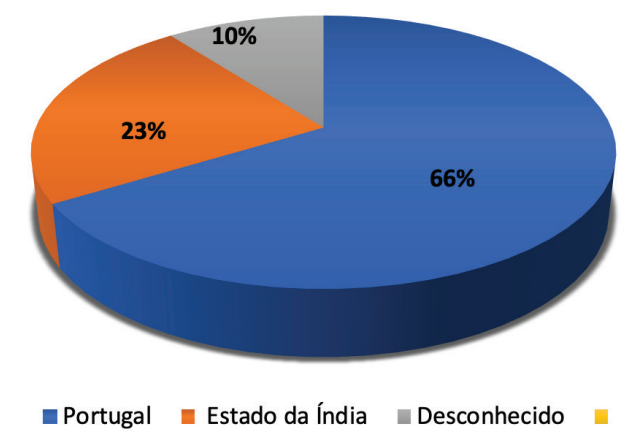

Fonte: ANTT- DRI, livro 43, fl. 302 e fl. 304v.

Relatione del caso successo assinala a precocidade de Pacheco, com uma trajetória de ascensão pelas letras - a religião "o levou tão para a frente, que o fez Mestre de Teologia". Simultaneamente foi acusado de ambicioso e traidor. A astúcia parece ter formado um dos traços da personalidade realçado na narrativa: "terrível sujeito movido por sua diabólica paixão" ("terribile soggetto mosso dalla sua diabolica passione”) (BNP, DRSA, ff 8v.). Sublinhe-se as características de comportamento de ingratidão e traição a confrades superiores que o honraram e favoreceram em "benefícios" e "favores" na Congregação da Índia Oriental

Frei Simão da Graça é tratado de modo igual, como um dos líderes da conspiração. Na pia batismal recebeu o nome de Simão Lopes de Sarzedas. Nasceu em torno do ano 1600 em Portugal, filho de Alvaro Gonçalves e Maria Gomes. Dois anos antes de Manoel da Purificação, com idade entre 19 e 20 anos, vestiu o hábito no Convento de Nossa Senhora da Graça de Goa, em 3 de abril de 1620, e professou um ano após, em 4 de abril de 1621. Provavelmente como Caparica, de mesma "unidade geracional"16, frei Simão frequentou o Colégio de Nossa Senhora do Pópulo da Congregação da Índia Oriental. Destacou-se do mesmo modo pelas letras: leitor de Artes, prior do convento de Malaca e leitor no convento de Macau em 1632 aos irmãos que haviam professado no ano anterior. Em Relatione del caso successo é apontado como uma das cabeças do motim, descrito nos seguintes vocábulos depreciativos: "sujeito terrível, inquieto e sem juízo".

Para os dois líderes do levantamento, não localizamos informaçôes do período anterior à entrada no convento dos gracianos de Goa. Chegaram ao Oriente na condiçâo de soldados,

\footnotetext{
${ }^{16}$ Sobre a categoria de unidade geracional ("Generationslage”) em Mannheim: "Estas unidades generacionales se caracterizan no sólo por significar diversas conexiones del acontecer vinculadas entre sí en el seno de una débil participación en común vivenciada por distintos individuos, sino también porque significan un modo de reaccionar unitario - un "agitarse juntos" y un modo de configurar que están conformados por un sentido semejante - de los individuos que están (en la medida en que lo están) directamente vinculados a una determinada conexión generacional" (MANNHEIM, 1993, p. 225).
} 
como tantos outros que avolumaram as estatísticas de desertores e escolheram a segurança dos conventos? De fato, a acusação do vice-rei Miguel de Noronha da habilitação de soldados ao claustro agostiniano explica em parte a ausência de informaçóes sobre o nome dos pais em número expressivo de moços portugueses que vestiam o hábito em Goa.

Um terceiro nome associado à direção do movimento é o do provincial eleito pelos insurretos Frei Antão de Jesus, no século Antão Correa de Azevedo, procedente da pujante cidade de Baçaim, na Província do Norte. Assim como o registro de Pacheco, também o de frei Antão não assinala os nomes dos pais. Vestiu o hábito agostinho em 25 de março de 1588. À época do motim com uma idade próxima a 70 anos, já ocupara por três vezes a posição de Definidor (REGO, 1955, p. 357), que no número de quatro serviam de apoio ao vigário provincial na orientaçáo para o "bom governo" e "reformação" dos agostinianos da Índia. Às vésperas do motim, ocupava a posição de reitor do Colégio do Pópulo de Goa, local com presença de moços, energia mobilizadora dos tumultos do mês de julho de 1638. Versado em História Eclesiástica, notas biográficas sobre Antão de Jesus vinculam o nome à escrita de uma peça de memória dos progressos que os agostinhos tinham feito em benefício da cristandade no Oriente - manuscrito intitulado "Tratado de algumas couzas memoraveis ate a Fundacao do convento de Gorgistao” (MACHADO, 1741, p. 184; REGO, 1955, p. 357-358).

\section{Os agostinhos da Índia entre Goa e Roma}

A data de 2 de junho de 1638 do Termo de Juramento dos conspiradores pode servir de baliza à deflagração do movimento. Por seu turno, Relatione del caso successo atribui o dia 17 de junho ao início do levantamento dos agostinhos, aos "sucessos nunca vistos nem ouvidos in jure entre religiosos". A data, quinze dias após o Termo de Juramento, assinalou o impacto dos desdobramentos da açáo dos sublevados pelas ruas no entorno da colina de Nossa Senhora do Rosário, território das instituiçôes agostinianas em Goa. Configurou-se um ambiente de "desordens e loucuras": os mais jovens, munidos de armas, saíam dos edifícios do Monte Santo, cantando pelas estradas com "tanta liberdade que mais pareciam soldados do que religiosos” (BNP, DRSA, fl. 25), em alusão à audácia na quebra do múnus eclesiástico. Ao grito de liberdade dos apoiadores do movimento, Leonardo da Graça, um frade venerável e mais velho, de crucifixo em mãos, grita por Misericórdia, num clamor de compaixão e perdáo aos sublevados pelo ato de rebeliáo contra o prelado Joáo de Mesquita, um brado do retorno à ordem. Em uma notação em memorial, Leonardo da Graça se autonomeia "africano de naçáo", natural de Tanger. Provável filho de Francisco de Azevedo e de Catherina Dias, o frade fez profissão no convento de Nossa Senhora da Graça de Lisboa, chegou ao Oriente na missão do ano de 1588 e atuou em importantes pontos da expansão das fronteiras agos- 
tinianas no leste: Ormuz, na fundação dos conventos de Ugulim, no Golfo de Bengala, e de Colombo, no no antigo Ceiláo, hoje Sri Lanka. Ademais, em 1602 fora nomeado pelo vice-rei Aires de Saldanha (1600-1605) embaixador na ilha de Socotorá — atual Socotra, à entrada do Golfo de Aden - , em mais uma tentativa de romanização de cristãos perdidos, associados à evangelização do apóstolo São Tomé, que, entretanto, reverteu em fracasso. ${ }^{17}$ O extenso capital religioso de serviços prestados à congregação da Índia não lhe serviu de cabedal como autoridade frente aos revoltosos. Logo, foi empurrado de volta à cela por frei Miguel de Cristo, um frade "velho e dos mais firmes nessa rebelião", signatário do Termo de Juramento, de profissão no convento de Goa e que chegara ao Índico no ano 1599.

Retornemos a uma carta do vice-rei Pero da Silva a Filipe III de Portugal, com data de 15 de setembro de 1638, 43 dias após a missiva sobre o levantamento com que iniciamos este artigo. Pero da Silva forneceu notícias agravantes do motim com a morte do provincial João de Mesquita ("apressada e em breves dias"). A missiva demonstra presteza em assinalar que o falecimento sucedera por causas naturais e acrescentou o "escândalo" despertado na conjuntura dos eventos da conspiração. Não deixa de destacar a rapidez com que os procuradores nomeados pelos agostinhos da Índia partiram por terra, sem aguardar a chegada do provincial sucessor, que estava em Cochim (ANTT-DRI, livro 43, fl. 118). Dessa feita, os procuradores partiram rumo a Roma, provavelmente pelo caminho de Alepo. Talvez, as lideranças do movimento tenham seguido por esse trajeto em direção ao Mediterrâneo. Aos frades Manoel da Purificação e Simão da Graça, designados procuradores, associou-se Ambrósio dos Anjos ${ }^{18}$, religioso vinculado às missóes da Pérsia e Geórgia, também signatário do Termo de Juramento em 2 de junho de 1638, que defenderia a causa dos agostinhos da Pérsia, Georgia e Baçorá na cúria papalina. ${ }^{19}$

Em Goa, os conflitos prolongaram-se após a partida dos procuradores dos independentistas. Na abertura da lista de sucessores ao provincial morto, João de Mesquita, o nome imediato foi de frei Nicolao das Chagas, que se encontrava em Cochim. Na vagância imediata do governo, procedeu-se a um processo interno de escolha de vigário substituto, em assento do definitório, reunido no convento goês, elevando ao governo o notável e longevo administrador do mosteiro de Santa Mônica, frei Diogo de Santa Anna. O legítimo sucessor nomeado pela Província de Portugal, frei Nicolao das Chagas, ao chegar a Goa, vociferou

\footnotetext{
${ }_{17}$ Sobre frei Leonardo da Graça remeto a ALONSO, 1985, p. 354, e REGO, 1955, p. 242-243.

${ }^{18}$ João Pinto, no século, filho de Cosme Pires e Catharina Alvares, nasceu em Lisboa. Com idade entre 18 e 19 anos, entrou para o convento dos gracianos de Goa em 27 de novembro de 1611 e fez profissão um ano à frente. Sacerdote, pregador e confessor, fundou o hospício de Xiras na Pérsia em 1623 e, cinco anos depois, o convento da Georgia (REGO, 1955, p. 402-403).

${ }^{19}$ Frei Ambrósio dos Santos foi contemplado com o grau de Presentado em Sagrada Teologia da Província de Portugal dos eremitas de Santo Agostinho pela Propaganda Fide em 9 de setembro de 1641, como prêmio aos 24 anos de dedicação ao trabalho missionário. Foi igualmente prefeito das missões da Pérsia, Georgia e Baçorá. Após sua morte em um naufrágio entre Itália e Portugal, provavelmente no ano de 1642, foi substituído na posição de prefeito (ALONSO, 1965, p. 276).
} 
contra Santa Anna, culpando-o de "intruso no governo" após o falecimento do antigo provincial (ANTT-MLIVR, 674, fls. 199v, 200). Acusou Santa Anna de espoliar a Congregação de três mil xerafins ${ }^{20}$ para a viagem dos procuradores a Roma, sem o aguardar. De fato, o numerário foi parte do acordo firmado pelos levantados na junta formada pelo arcebispo franciscano D. Frei Francisco Mártires e os inquisidores António de Faria Machado e Jorge Secco de Macedo no convento dos gracianos de Goa, conforme informa ao monarca o vice-rei Pero da Silva na carta de 2 de agosto de 1638, acima citada.

O imbróglio entre Chagas e Santa Anna configura um episódio a mais de competição entre religiosos, demonstrando clivagens internas no próprio grupo de reinóis, aguçando as tensóes e os conflitos latentes nas disputas por poder. Embora o nome de frei Diogo de Santa Anna não constasse entre os signatários do Termo de Juramento, passagens de Relatione del caso successo indicam sua proximidade com os conterrâneos que vestiram o hábito no convento de Goa. Não surpreende a escrita repleta de elogios em um testemunho à Propaganda Fide, na pena de Santa Anna, à designação de frei Manoel da Purificação para a regência de Sagrada Escritura, enviado com data de 30 de outubro de 1638, quatro meses depois dos eventos da conspiração. Santa Anna confirma a retidão e limpeza de sangue de Purificação. ${ }^{21}$

Descrito como ambicioso e traidor em Relatione del caso successo, frei Manoel da Purificação foi o principal nome a transitar pela cúria romana na posição de procurador dos agostinhos levantados e identificado como líder do movimento.

Não se localizam registros da época de chegada dos agostinhos da Índia à cidade celestial, mas de certo foi em algum momento entre o ano de 1639 e o início do seguinte. ${ }^{22}$ Duas datas servem de baliza aos desdobramentos do movimento nos espaços de Lisboa e Roma: uma primeira refere-se à realização do capítulo da Província de Portugal em maio de 1639, no convento de Nossa Senhora da Graça de Lisboa, que elegeu frei Luis Coutinho como procurador na representação e defesa dos interesses do braço português em Roma, contrários à vindicação de independência dos agostinhos da Índia. Por sua vez, a datação de 31 de agosto de 1640 corresponde à realização na cúria papal de uma reunião da congregação particular sobre a separaçáo dos agostinhos da Índia da tutela da Província de Portugal. Os cardeais Bernardino Spada, Giambattista Pamphili (a partir de 1644, papa Inocêncio X), Giovanni Francesco Guidi di Bagni, Giovanni Battista Pallotta e o capuchinho Antônio Barberi-

\footnotetext{
${ }^{20}$ Xerafim corresponde à moeda de prata, com 3.000 réis, corrente em Goa (SUBRAHMANYAM, 1993, p. 395). Como parâmetro de comparação, 3.000 xerafins correspondiam a um dote e meio das monjas de véu preto do Mosteiro de Santa Mônica (cada dote no montante de 2.000 xerafins).

${ }_{21}$ "Nulla preterea inhabilitatis, Suspentionis, privationis, alia ue paena pro culpa aliqua grauissima, uel grauiori vllo unquam tempore fuisse punitum, quin imo, antiqua generis nobilitate omissa, integritate uitae ac morum grauitate, ornatum esse testamur. Jnquorum omnium fidem, ac veritatis expressae Testimonium, hanc nostram patentem Testificationem nomine nostro firmatam rogati dedimus" (ARCHIVIO STORICO DE PROPAGANDA FIDE, v. 402, 230r).

${ }^{22}$ Carlos Alonso sugere que frei Manoel da Purificação chegou na primavera de 1640 e frei Ambrosio dos Anjos, alguns meses depois, no outono (ALONSO, 1967, p. 176-177).
} 
ni, um dos cardeais-sobrinhos do pontífice Urbano VIII (1623-1644), formaram a assembleia circunscrita ao caso do levantamento no âmbito da Propaganda Fide (ANTT-MLIVR, n. 674 , fl. 325).

Aos cardeais em Roma, os agostinhos da Congregação da Índia Oriental listaram justificativas e razões para a criação de uma província autônoma (BNP-DRSA, fls. 93, 93v.). Dos motivos elencados sobressai a denúncia de que os religiosos enviados do reino desejavam sempre domínio absoluto. Acusam os vigários provinciais eleitos em Portugal para a Índia de agirem em detrimento da Congregação da Índia Oriental. Cometem irregularidades, sem receio de castigo e repreensão dos superiores, não só pela distância, mas também por prática usual do envio de donativos aos superiores de Portugal. Alguns prelados por alguma culpa (escrúpulo) não chegavam a finalizar a prelazia. $\mathrm{O}$ registro prossegue apontando as dificuldades enfrentadas pelos religiosos da Índia, impedidos de encaminhar cartas de recurso à sede apostólica, uma vez que dependiam da intermediação da Província de Portugal. Acrescentam que muitos bons religiosos da Índia não eram eleitos em dignidade e ofícios, já que não remetiam donativos a religiosos da casa máe de Lisboa. Protestam que muitos dos donativos foram aplicados pelo coletor apostólico Lorenzo Tramallo (1627-1634) ${ }^{23}$ na comunidade de Portugal, recursos desviados da congregaçáo oriental. Na resposta ao documento dos sublevados, Propaganda Fide nega a veracidade ("è bugia") (BNP-DRSA, fl. 106) do destino dos donativos e defende o coletor: define preceitos, impedindo que da Índia fossem enviados donativos aos religiosos da província além de dez escudos, sob pena de excomunhão. Adiante é esclarecida a devoluçâo de valores ao provincial de Portugal, com efeito um retorno do numerário do próprio, enviado para a compra de uma "pedra de porco espinho" - denominação para um volume maciço encontrado no fel do porco que se tornou célebre em Portugal pelas qualidades medicinais, um alívio às "peçonhas", conforme citado por Garcia Orta em Colóquios dos simples, e drogas he cousas medicinais da India.... Ou seja, o que é de sublinhar nesse caso, embora tratado como de menor valor, a menção à pedra de espinho revalida a acusaçáo dos independentistas sobre a troca de presentes e valores entre agostinhos da Índia e do reino, na pressão por provimento de cargos.

Queixas e denúncias assentadas pelos levantados pressupunham acusaçôes ao governo tirânico dos vigários e, por extensão, da Província de Portugal. Assinale-se a apropriação de tópicas do pensamento teológico-político da segunda escolástica correntes na literatura de arbítrios que vicejara no Estado da Índia nas primeiras décadas do século XVII. No conjunto de relatos é abusivo o uso da categoria de tirania, disseminada nos mundos ibéricos na influência decisiva de Tácito e Sêneca ao estoicismo de Justus Lipsius (1547-1606). Um entendimento da concepção de governo derivado de Deus, que atribui aos povos a posse do direito natural de poder e pari passu a condiçáo de rompimento do pacto de

\footnotetext{
${ }^{23}$ Foram sucessores de Lorenzo Tramallo, Alessandro Castracani (30 de setembro de 1634-1640) e Girolamo Battaglia (30 de setembro de 1640 a 1646).
} 
sujeição, pela destituição de maus governantes que tendessem a fomentar a desordem no rompimento da unidade dos corpos políticos. É uma tópica de ampla circulaçâo nos livros de lugares comuns dos letrados e integrada à linguagem política rotineira dos diversos segmentos sociais.

Os levantados acusavam a Província de Portugal de governo arbitrário e independente no desrespeito aos direitos adquiridos pelos religiosos da Índia. Lembram que o breve de Clemente VIII (1596), expedido a favor da Província de Portugal, limitava a dependência dos agostinhos da Índia ao tempo de sua criação, em virtude da ausência de sujeitos capazes. Destacam que, após anos, somavam significativo número de sujeitos capazes de governo, em um quadro de crescimento e expansão da congregação, visível com o aumento do número de conventos no Oriente. Por fim, reforçam os prejuízos à ação dos agostinhos da Congregaçáo da Índia Oriental com a manutenção do vínculo de dependência com os gracianos de Portugal.

Em resposta ao documento das razôes dos levantados, o juízo da administração cardinalícia pondera que a origem da Congregação da Índia Oriental foi uma ação inicial da Província de Portugal e, portanto, não deveria ser espoliada sem causa. Pondera acerca das consideraçôes advertidas no reinado de $\mathrm{D}$. Sebastiáo - período do envio dos primeiros missionários da religião de Santo Agostinho ao Índico -, que apontam o efeito negativo da habilitação de religiosos nascidos na Índia. Alerta para o fato de os portugueses que vestiam o hábito na Índia serem geralmente soldados, filhos de marinheiros e consequentemente não letrados ("idioti”). Segundo a ótica de Roma, o predomínio da junção de soldados portugueses e sujeitos indianos ("sogetti Indiani”) em pouco tempo deterioraria a Congregação, perdendo o resplendor no qual fora mantida pelos religiosos enviados de Portugal (BNP-DRSA, fl. 103). Dos religiosos reinóis provinham as garantias de valor e zelo à propagação da fé e com isso a observância da religião. E, o arrazoado assinala como modelos os religiosos da Companhia de Jesus e os carmelitas descalços, ao recusar a entrada de naturais da Índia em suas fileiras. Ademais, confirma que a Congregação da Índia Oriental se governava pelo definitório da Província de Portugal, segundo a concessão apostólica, com poderes de escolha do vigário provincial, de quatro definidores e dois visitadores. Esclarecem que nos casos de excessos do vigário provincial, o mesmo definitório provia mecanismos de castigo aos culpados. Em uma eventual separação, o controle sobre os desregramentos do vigário provincial e demais religiosos passaria ao prelado geral da ordem em Roma. As puniçôes seriam mais difíceis de aplicabilidade por falta de informaçóes das acusaçóes, em virtude da grande distância entre Índia e Europa e face aos obstáculos de navegação.

Segundo as constituiçóes da Ordem dos Eremitas de Santo Agostinho, as eleições eram bianuais, adiciona a Propaganda Fide e, portanto, a realização de um capítulo provincial em Goa, na projeção de uma possível separação, exporia as dificuldades dos deslocamentos das viagens por mar, condicionadas ao sistema de ventos e aos riscos da passagem por regióes de infiéis. Os cardeais lembram que apenas 12 dos conventos, a maioria de poucos religiosos, 
estariam presentes ao capítulo geral em Goa. Dão os exemplos de China e Malaca, com condiçôes favoráveis de navegação no mês de abril, por um lado, e Ormuz e Mombaça, no mês de outubro, por outro. Além do mais, segundo o parecer, a participação dos vogais no capítulo geral consumiria recursos em viagens que eram destinados à propagação da fé, principal objetivo da religião. Uma vez que a maioria dos conventos era pobre e de dois a quatro religiosos, as casas ficariam por longos períodos sem governo. Em vista desses argumentos, considerou-se um desvio das missões em que a participação no capítulo era de nenhum ganho. A peça cardinalícia lembra a condição dos agostinhos da Índia de súditos do rei de Portugal e do risco com a separação da retirada de ajuda da coroa às missóes na Ásia.

Aliás, advertia-se que à separação sucederia uma divisão interna do grupo de religiosos da Congregação da Índia Oriental. Ou seja, cresceriam as tensóes entre os naturais do Estado da Índia e os portugueses que vestiam o hábito na Índia, na disputa pela prelatura. Ademais, atenta que os procuradores dos agostinhos da Índia se recusaram a exibir a procuração aos eminentes cardeais e de qualquer modo não representavam a coletividade, mas somente alguns poucos religiosos levantados: "deve sapere, che quella non fu sollevatione di tutta la Congregatione ma solo di tre, o quatro religiosi, il capo del quale fu il Padre fra Emanuel della Purificatione asserto procuratore..." (BNP-DRSA, fl. 105).

As extensas peças da cúria romana grifam as tintas da percepção de superioridade missionária dos europeus. $\mathrm{O}$ arrazoado reitera a desqualificação do movimento, reproduzindo a acepção negativa do clero nascido e formado na Índia, recorrente na percepção europeia, conforme as denúncias propaladas no curto tratado Relação defensiva dos filhos da Índia Oriental (,,), dado ao prelo, em 1640, na pena do frade menor Miguel da Purificação, nascido na Índia e filho de pais portugueses (XAVIER, 2006; FARIA, 2013).

Por fim, conforme as ponderações da Propaganda Fide, não eram esperadas novas altercaçôes entre os religiosos da Índia. Destaca a paz selada na eleição do novo vigário provincial com a morte de João de Mesquita, vigário motivador da sedição. Ou seja, a tessitura narrativa reduz o movimento à atuação de uma minoria de religiosos arruaceiros. No entanto, a congregação cardinalícia tendeu a transferir a resolução ao geral da Ordem dos Eremitas de Santo Agostinho em Roma.

Por sua vez, o relato da Propaganda Fide cita professos no convento goês que, no passado, ocuparam cargos variados no Oriente, incluindo um provincial anterior. Com certeza, o texto alude a frei Luis Coutinho, vigário geral entre abril de 1629 e outubro de 1632, que professou no convento de Nossa Senhora da Graça, na cidade de Goa, em dezembro de 1607. Com efeito, desde a chegada ao Oriente dos primeiros agostinianos no ano 1572, foi o primeiro com profissão em Goa a ocupar o provincilado. ${ }^{24}$ No lugar de procurador da Pro-

\footnotetext{
${ }^{24}$ Luis da Cruz ou Coutinho, natural de Lisboa, da freguesia do Loureto, era filho de Felipe Coutinho e Margarida Franca. Vestiu o hábito em 6 de dezembro de 1606 aos 25 anos. Coutinho estudou Filosofia no colégio do Pópulo de Goa e Teologia no colégio de Coimbra. Ocupou a posição ainda de vigário geral da Província de Portugal no ano de 1649 (REGO, 1955, v. XII, p. 98, 284, 387-388).
} 
víncia de Portugal, Luis Coutinho foi mais um dos agostinhos a circular na cidade celeste em torno dos anos 1639, 1640. De um mesmo conjunto de "experiências compartilhadas" 25 no Oriente, Luis Coutinho e Manoel da Purificação, conforme o conjunto documental da Propaganda Fide, mantiveram, contudo, relativa distância na deambulação pela cúria romana. Uma notação da secretaria, com cópia encaminhada a António Barberini, Cardeal de Sant'Onofre, menciona um pedido de Luis Coutinho de leitura de um Memorial entregue por Manoel da Purificação na congregação romana em 14 de fevereiro de 1639. Porém, o escrito fora retirado pelo padre prior geral da ordem agostinha em Roma. Ao pedido de Luis Coutinho, o geral dos agostinhos recusou a entrega do Memorial por não o reconhecer como procurador da Província de Portugal, embora fosse notória sua posição, conforme a Propaganda Fide. O mesmo registro adverte, entretanto, a ligaçáo em conluio entre o geral da ordem agostiniana e o procurador dos agostinhos da Índia, frei Manoel da Purificação. ${ }^{26}$ Um episódio a mais que confirma o peso das relaçóes clientelares no universo das ordens regulares, aproximando religiosos das conquistas aos centros decisórios europeus, Goa, Lisboa e Roma.

A notar em Relatione del caso successo o vocábulo italiano "sollevamento" na tradução para o português de levantamento. A palavra "sollevamento" associava-se à presença de armas no conflito, o que aproximou o movimento dos agostinhos da Índia das sublevaçóes de marinheiros e soldados no Antigo Regime, como já destacado acima. O uso do termo na significação do movimento reforçou uma das acusaçôes aos levantados de uma origem na soldadesca, retirando a qualidade de letramento inerente ao múnus eclesiástico. Em Relatione del caso successo, e em peças variadas da documentação remetida à Propaganda Fide, a escrita traçou um perfil de soldados desertores aos portugueses que vestiram o hábito no Convento de Nossa Senhora da Graça de Goa.

\section{Consideraçóes finais}

Qual é a percepção sobre agostinhos da Índia a partir de Roma? É mesmo assinalável a circulação nos corredores da cúria papal, em época próxima à deambulação dos agostinhos, do franciscano nascido na Índia, já citado acima, frei Miguel da Purificação, procurador geral da Província de S. Tomé da Índia Oriental. A ida de Purificação foi motivada por demandas

\footnotetext{
${ }^{25}$ Sigo a abordagem de Mannheim, já indicada anteriormente na nota de rodapé número 16. Atento à reflexão acerca das vivências comuns dos religiosos na interação entre sujeitos de idades cronológicas diversas na circulação e aprendizado de formação em um mesmo ambiente de letramento mediado por percepçóes das açôes de evangelização abalizadas pelas instituiçóes agostinianas em Goa.

26 "Um memoriale dato a cotesta Sac. congne Sotto le 14 de febraro per parte del P. fra Emanuel della Purificatione concernente interessi della Cong. Agostiniana dell' India orientale, fu rimesso pro informatione a fra Luigi Contigno Proc.re della Prov.a di Portugallo, della quale la Cong.ne depende" (BNP-DRSA, fl. 113).
} 
em torno da confirmação da autonomia das províncias dos frades franciscanos de São Tomé e da Madre de Deus, processos que se alongavam desde o início do século, pelejas por fim solucionadas no Capítulo Geral celebrado em Roma no ano de 1639 (XAVIER, 2014, p. 99). ${ }^{27}$ No âmbito da Propaganda Fide, os religiosos da Índia buscavam dirimir a posição de inferioridade a que se percebiam projetados frente à açâo dos confrades do reino. Para os agostinhos da Índia, o acesso à cidade pontifícia era de fato impedido pela condiçâo de subalternidade à Província de Portugal. No século XVII, o motim de junho de 1638 facultou uma oportunidade de representantes dos frades independentistas seguirem o caminho de Roma.

$\mathrm{Na}$ chancelaria da Propaganda Fide, a eventualidade de autonomia dos agostinhos da Índia transformou-se em derrota. A construção discursiva da burocracia romana tendeu a reduzir o movimento à participação de número diminuto de religiosos, como também a inabilitar o braço dos agostinhos da Índia, vistos como provindos de segmentos de soldados e de baixo letramento. Anuncia os riscos de acirramento das rivalidades entre os grupos de portugueses do reino e naturais do Estado da Índia. Contudo é interessante retomar um dos eixos de justificativa elencado pela argumentação da Propaganda Fide, em virtude do potencial explicativo da dinâmica de poderes na Ordem dos Eremitas de Santo Agostinho, de forte presença de casas súditas aos Habsburgo de Espanha. Em 31 de agosto de 1640, o parecer negativo da burocracia romana aos independentistas acrescentou uma advertência aos riscos da questão da separação dos agostinianos da Índia ser levada ao capítulo geral da ordem, com maioria de representantes da facção espanhola. Comparou com a recente confirmação das demandas dos franciscanos da Índia de autonomia e criação de províncias. Esclarece que, enquanto entre os padres observantes menores as pendências de separação e de formaçáo de novas províncias se resolviam em definitórios de oito a dez padres, com uma maioria de religiosos não dependente da Casa da Áustria, nos agostinhos as decisões se davam no capítulo geral com uma representação de 54 conventos, entre os quais 33 compunham a facção espanhola, decerto contrários à separação da Congregação da Índia Oriental da Província de Portugal em apoio aos desígnios do monarca Habsburgo. ${ }^{28}$

O quadro das missões agostinianas hispânicas no eixo do Pacífico, embora acusasse de modo similar os processos de nativização dos conventos, as soluçôes decerto facultaram

\footnotetext{
${ }^{27}$ E, ainda, considere-se a recente circulação em Roma do brâmane Mateus de Castro (1594-1677), então investido por bispo do anel in partibus infidelium, futuro autor de Espelho de Bramanes. Embora educado no colégio franciscano dos Reis Magnos de Bardez, teve a admissão no colégio de São Boaventura em Goa sucessivamente negada e por fim foi ordenado sacerdote em Roma, sendo nomeado agente missionário da Propaganda Fide. Roma fora o centro de recepção dos conflitos e tensôes dos segmentos clero nativo ou de profissão na Índia. Sobre Mateus de Castro cf. XAVIER e ŽUPANOV, 2015, p. 21-23.

${ }^{28}$ Confirmam essa argumentação, os termos do manuscrito: "E circa quello che li avversarii ante pongono, che rimettendosi la rislutione di questo negotio al Capitolo Generale, possa progiudicare particolarmente a loro intento la fattione spagnola per il gran numero de suo i voti, stimando non esser mente di sua Maesta si faccia tal separat.ne si rispondi che pare vogliano servirsi dell' E.E. VV. per instromento contra la fattione spagnola, e com questo dare occasione a sua Maesta di contradire a quanto si risolvera" (BNP-DRSA, fl. 106v.) [grifos meus].
} 
horizontes promissores na criação de novas províncias. Nos alvores do século XVII, em Nova Espanha, a província agostiniana do Santo Nome de Jesus (1565) configurou-se como uma "instituição criolla", fato que acirrara as disputas com grupos de "peninsulares” (espanhóis), desencadeando a formação da Província de São Nicolao de Tolentino em Michoacán no ano de 1603. As competiçóes foram endêmicas às províncias agostinianas de Nova Espanha (GARCIA, 1990, p. 25-35), ao longo do eixo do Pacífico em conjunturas diversas, do Peru às Filipinas, pipocaram conflitos e enfrentamentos entre clérigos regulares locais e espanhóis, com forte componente de antagonismo e demandas locais de autogoverno, seja na criaçáo de novas províncias, seja pelas reivindicaçôes de acesso ao governo pelos segmentos autóctones "criollos". ${ }^{29}$

Porém, para os agostinhos da Índia, uma resposta da notável congregação cardinalícia conclusiva aos rogos independentistas não foi anunciada. De algum modo, cabe observar a leniência em tomar decisões envolvendo controvérsias e tensões com os Habsburgo de Espanha. Talvez, o processo de independência dos agostinhos da Índia encontrara na restauração brigantina de dezembro de 1640 um retraimento ao seu avanço.

Se o Padroado Real português condicionou os regulares à posição de súditos do monarca, estes deviam ademais obediência às respectivas ordens e à Santa Sé. Em direção a Roma corriam demandas de resolução de disputas e controvérsias jurisdicionais e de direito canônico em torno das missóes, e de maneira vigorosa após a entrada em cena da Propaganda Fide.

As tensôes e conflitos dos agostinhos da Índia persistiam. Em 22 de fevereiro de 1643, um registro na Mesa da Consciência e Ordens adverte acerca das "inquietaçôes dos agostinhos na eleição do prelado" e da interferência do coletor pontifício no processo. A mesma advertência requer que o coletor fosse prevenido de náo mais interferir na concessão de patentes aos agostinhos da Índia, como também que o arcebispo Dom Frei Francisco Mártires zelasse pela paz dos agostinhos em Goa. Mais tarde, em 20 de fevereiro de 1645, um novo requerimento ordena aos provinciais do reino que interceptem despachos transportados por frades vindos de Roma, como também que não se abram vias de eleiçôes e prorrogaçôes de prelados que o vice-coletor mandasse (ARANHA, ANTT-Mesa da Consciência e Ordens, liv. 304).

Tal quadro não impediria que novos episódios de conflagraçôes assolassem os agostinhos em Goa. Logo em 1647, assinala-se, um segundo caso de sublevação em que os levantados fizeram prisão ao vigário provincial, frei Alexandre de Noronha. Em seguida, foi solto a mando do vice-rei. Um novo incidente contra o prelado culminou no seu assassinato em janeiro de 1648. Segundo os termos da carta do vice-rei D. Filipe de Mascarenhas (16451651) ao soberano Bragança, os insurretos arrombaram a porta da cela de frei Alexandre de Noronha, o mataram por afogamento e, em seguida, o jogaram de uma janela (ANTT-DRI,

\footnotetext{
${ }^{29}$ Segundo Bernad Lavallé, o termo "criollo" precede aos nascidos em território americano, não constitui uma categoria étnica, mas remete a procedências variadas, desde espanhóis "criollizados" e descendentes a mestiços e mulatos “acriollados”. Veja-se LAVALLÉ, 1993, p. 25, p. 163.
} 
livro 57, fl. 504). Um "caso atroz", na expressão de D. João IV na missiva ao vice-rei do início do ano de 1649, em que ordenou de imediato o embarque dos culpados ao reino antes de escaparem para a "terra de mouros". ${ }^{30}$

Nas três décadas seguintes ao levantamento de 1638, parte da rede de conventos agostinianos na Ásia foi encerrada nos episódios das sucessivas perdas de possessóes portuguesas em conjunturas variadas de derrotas no leste para neerlandeses (Malaca, Colombo e Negapatão no Ceilão, Cochim, São Tomé de Meliapor) e potentados locais, como no caso dos omanitas no Golfo Pérsico e a ocupação de Mascate. A nova conjuração de 1647 é reiterativa de conflitos que confirmaram a instabilidade na funçáo da prelatura no provincialado da Congregação da Índia Oriental na segunda metade do seiscentos reforçando as tensôes latentes dos agostinhos na Índia.

\section{Fontes documentais}

ARANHA, Lázaro Leitão. Meza das tres Ordens militares. Da jurisdição da Ordem de Cristo por tudo o q/ toca o Ultramar, 1731. III, fl. 72. Arquivo Nacional da Torre do Tombo - Mesa da Consciência e Ordens, liv. 304.

ARCHIVIO STORICO DE PROPAGANDA FIDE (ROMA), SOCG, v. 402, 230r.

ARQUIVO DO PATRIARCADO DE LISBOA (APL). Livro dos Statutos Eleiçoes, e mais cousas tocantes à Nossa Congregação da India, 1632. Mss 336.

ARQUIVO NACIONAL DA TORRE DO TOMBO (ANTT-DRI). Resposta do Provincial de $\mathrm{St}^{\circ} \mathrm{Ag}^{\circ}$. pello que toca a sua Relligiaó aos pontos das cartas de $\mathrm{S}$. Mage fundadas na informação do Conde de Linhares. Documentos Remetidos da Índia (DRI), livro 35, fls. 177-180v, fl. 177.

ARQUIVO NACIONAL DA TORRE DO TOMBO (ANTT-DRI). Carta sobre a conspiração que os Religiosos de S. Agostinho trocarão contra o seu Vigario Provincial e Prior da mesma Caza, mostrando que os não conhecião por seus Prelado. Documentos Remetidos da Índia (DRI), livro 43, fls. 97-98v.

ARQUIVO NACIONAL DA TORRE DO TOMBO (ANTT-DRI). Carta sobre a morte de Frei João de Mesquita. Vigário Provincial do Convento de S. Agostinho. De 15 de setembro 1638. Documentos Remetidos da Índia (DRI), livro 43, fl. 118.

ARQUIVO NACIONAL DA TORRE DO TOMBO (ANTT-DRI). Termo de certo

\footnotetext{
${ }^{30} \mathrm{O}$ monarca relatou, ainda, que deu notícia do episódio ao Provincial da ordem em Lisboa, que, por seu turno, solicitou cartas a Roma de confirmação da jurisdição do caso para efetivar o "castigo" aos culpados (ANTT-DRI, livro 60, fl. s/n.) À morte de Alexandre de Noronha sucede-se uma fase de crise no reconhecimento da autoridade do prelado que afetou as prelaturas de frei Antônio de Cristo e frei Vicente Caldeira.
} 
juramento que fizerão os Religiosos de S. Agostinho, 2 de junho de 1638. Documentos Remetidos da Índia (DRI), livro 43, fl. 302 e fl. 304v.

ARQUIVO NACIONAL DA TORRE DO TOMBO (ANTT-DRI). Carta do vice-rei ao monarca sobre a morte do provincial dos agostinhos, 15 de janeiro de 1648. Documentos Remetidos da Índia (DRI), livro 57, fl. 504.

ARQUIVO NACIONAL DA TORRE DO (ANTT-DRI). Carta de D. João IV sobre o caso da morte do Provincial da Congregaçáo de Santo Agostinho, frei Alexandre de Noronha a 23 de janeiro de 1649. Documentos Remetidos da Índia (DRI), livro 60, fl. s/n.

ARQUIVO NACIONAL DA TORRE DO TOMBO (ANTT-MLIVR). Memórias da Congregação de Santo Agostinho no Oriente. Manuscritos da Livraria (MLIVR), n. 674, fls. 199 v, 200, 325.

BIBLIOTECA NACIONAL DE PORTUGAL (BNP). Documentos religiosos relacionados com a Ordem de Santo Agostinho (DRSA). Manuscrito, Códice 1498 [437fls.], fl. 1-114v. SANTA ANNA, Diogo. Relaçam verdadeira do milagroso portento, \& portentoso milagre, q[ue] aconteceo na India no Santo Crucifixo, q[ue] està no coro do observantissimo mosteiro das Freiras de S. Monica da cidade de Goa, em oito de fevereiro de 636. Lisboa: Manoel da Sylva, 1640. SILVA, José Justino de Andrade e. Carta Régia de 28 de fevereiro de 1636. Colleçâo Chronologica da Legislação Portugueza 1634-1640. Lisboa: Imprensa de J.J. A. Silva, 1855.

\section{Referências}

ALMEIDA, Candido Mendes de (ed.). Codigo Philippino, ou Ordenaçôes e leis do Reino de Portugal: recopiladas por mandado d'El-Rey D. Philippe I. 14. ed. Tomo IV. Rio de Janeiro: Typ. do Instituto Philomathico, 1870.

ALONSO, Carlos. Misiones de la Orden de San Agustín en Georgia (1628-1693). Analecta Augustiniana, n. 28, 1965, p. 219-280.

ALONSO, Carlos. Los Mandeos y las misiones católicas en la primera mitad del siglo XVII (= Orientalia Christiana Analecta, 179). Roma: Pontificium Institutum Orientalium Studiorum, 1967.

ALONSO, Carlos. Las profesiones de la provincia de Portugal durante el periodo 15131631. Analecta Augustiniana, n. 48, 1985, p. 331-389.

ALONSO, Carlos. Alejo de Meneses, O.S.A. (1559-1617), Arzobispo de Goa (1595-1612). Estudio biográfico (= Estudios de Historia Agustiniana, 4), Ed. Estudio Agustiniano, Valladolid, 1992. 
BOCARRO, António. Livro das Plantas de todas as fortalezas, cidades e povoaçóes do estado da Índia Oriental. In: PEREIRA, A. B. Bragança (ed.) Arquivo Português Oriental (Nova Série). Goa: Tipografia Rangel, Tomo IV, v. II, 1600-1699, parte I, p. 59-60.

BOXER, C. R. O Império Colonial Português (1415-1825). Lisboa: Edições 70, 1981.

FARIA, Patricia Souza de. A conquista das almas do Oriente: franciscanos, catolicismo e poder colonial português em Goa (1540-1740). Rio de Janeiro: FAPERJ-7 Letras, 2013.

FARIA, Patricia Souza de. Mais soldados e menos padres: remédios para a preservação do Estado da Índia (1629-1636). História Unisinos, v. 16, n. 3, set./dez. 2012, p. 357-368.

FLANNERY, John M. The mission of the Portuguese Augustinians to Persia and beyond (16021747). Leiden-Boston: Brill, 2013.

FLOOR, William. The Persian Gulf. A political and economic history of five port cities 15001730. Washington: Mage Publishers, 2006.

GARCÍA, Antonio Rubial. Uma monarquia criolla. México: Direción Geral de Publicaciones del Cons. Nac. para La Cultura y las Artes, 1990.

GONÇALVES, Margareth de Almeida. A edificação da cristandade no Oriente português: questôes em torno da ordem dos eremitas de Santo Agostinho no limiar do século XVII. Revista de História (São Paulo), n. 170, p. 107-141, jan.-jun., 2014. Disponível em: http:// dx.doi.org/10.11606/issn.2316-9141.v0i170p107-141.

GUTIÉREZ, David. Los Agustinos desde el protestantismo hasta la restauración católica. 15181648. V. II. Roma: Institutum Historicum Ordines Fratrum s. Augustini, 1971.

HESPANHA, António Manuel. Caleidoscópio do Antigo Regime. São Paulo: Alameda, 2012. LAVALLÉ, Bernard. Las promessas ambiguas: ensayos sobre el criollismo colonial en los Andes. Lima: Instituto Riva-Agüero/Pontificia Universidad Católica del Peru, 1993.

MACHADO, Diogo Barbosa. Bibliotheca Lusitana historica, critica e cronologica. Tomo 1. Lisboa: Officina Patriarcal de Francisco Luiz Ameno, 1741.

MANNHEIM, Karl. El problema de las generaciones. [1928] REIS. Revista Española Investigaciones Sociológicas, n. 62, 1993, p. 193-242.

MENDONÇA, Delio de. Conversions and citizenry: Goa under Portugal. 1510-1610. New Delhi: Concept Pub., 2002.

PINTO, Carla Alferes. Notas para o estudo do mecenato de d. frei Aleixo de Meneses: os recolhimentos da Misericórdia de Goa. Anais de história de além-mar, VII, 2006.

PINTO, Carla Alferes. Traz à memória a excelência de suas obras e virtudes. D. frei Aleixo de Meneses (1559-1617), mecenas e patrono. Anais de história de além-mar (Lisboa), v. 12, 2011, p. 153-180.

REGO, António da Silva. Documentação para a história das Missóes do Padroado Português do Oriente. Índia. V. XI. Lisboa: Arquivo Geral do Ultramar, 1955. 
RODRIGUES, Vitor Luís Gaspar. "A guerra na Índia”. In: BARATA, Manuel Themudo; TEIXEIRA, Nuno Severiano (dir.). Nova história militar de Portugal, v. II, Lisboa, Círculo de Leitores, 2004. p. 198-223.

SILVA, José Justino de Andrade e. Colleção Chronologica da Legislação Portugueza 16341640. Lisboa: Imprensa de J.J. A. Silva, 1855.

SOUSA, Bernardo Vasconcelos (dir.). Ordens religiosas em Portugal. Das origens a Trentoguia histórico. Lisboa: Livros Horizonte, 2005.

SUBRAHMANYAM, Sanjay. O Império Asiático Português (1500-1700). Uma história politica e económica. Lisboa: DIFEL, 1993.

TORGAL, Luís Reis. Ideologia política e Teoria do Estado na Restauração. V. II. Coimbra: Biblioteca Geral da Universidade, 1982.

XAVIER, Ângela Barreto. Itinerários franciscanos na Índia seiscentista, e algumas questôes de história e de método. In: Lusitania Sacra, $2^{a}$ série, 18, 2006, p. 87-116.

XAVIER, Ângela Barreto. A invenção de Goa. Poder imperial e conversóes culturais nos séculos XVI e XVII. Lisboa: Imprensa de Ciências Sociais, 2008.

XAVIER, Ângela Barreto. Fr. Miguel da Purificação, entre Madrid y Roma. Relato del viaje a Europa de un franciscano portugués nacido en la India. Cuadernos de Historia Moderna, 2014, Anejo XIII, 87-110.

XAVIER, Ângela Barreto. Punctus contra punctum, 'Cleros nativos', tensão e harmonia no império português. In: LARCHER, Maria Madalena Oudinot; MATOS, Paulo Lopes (coords.). Cristianismo e Império, conceitos e métodos v. 1. Ebooks. Lisboa: Cham, 2017. XAVIER, Ângela Barreto; ŽUPANOV, Ines G. Ser brâmane na Goa da Época Moderna, Revista de História - USP, São Paulo, n. 172, p. 15-41, jan.-jun., 2015. 